\title{
In vitro biological activity of tannins from Acacia and other tree fruits: Correlations with colorimetric and gravimetric phenolic assays
}

\author{
V. Mlambo ${ }^{1 \#}$, F. L. Mould ${ }^{1}$, T. Smith ${ }^{1}$, E. Owen ${ }^{1}$, J.L.N. Sikosana ${ }^{2}$ and I. Mueller-Harvey ${ }^{1}$ \\ ${ }^{1}$ Department of Agriculture, School of Agriculture, Policy and Development, The University of Reading, \\ Earley Gate, P.O. Box 237, Reading, RG6 6AR, UK. \\ ${ }^{2}$ Matopos Research Station, Department of Agricultural Research and Extension, P.Bag K5137, \\ Matopos, Bulawayo, Zimbabwe
}

\begin{abstract}
This study was designed to investigate impact of tannins on in vitro ruminal fermentation parameters as well as relationships between concentration and in vitro biological activity of tannins present in tree fruits. Dry and mature fruits of known phenolic content harvested from Acacia nilotica, A. erubescens, A. erioloba, A. sieberiana, Piliostigima thonningii and Dichrostachys cinerea tree species were fermented with rumen fluid in vitro with or without polyethylene glycol (PEG). Correlation between in vitro biological activity and phenolic concentration was determined. Polyethylene glycol inclusion increased cumulative gas production from all fruit substrates. The largest increase $(225 \%)$ after $48 \mathrm{~h}$ incubation was observed in $D$. cinerea fruits while the least (12.7\%) increase was observed in A. erubescens fruits. Organic matter degradability (48 h) was increased by PEG inclusion for all tree species except $A$. erubescens and $P$. thonningii. For $D$. cinerea fruits, colorimetric assays were poorly correlated to increases in gas production due to PEG treatment. Ytterbium precipitable phenolics ( $\mathrm{YbPh}$ ) were also poorly correlated with response to PEG for A. erioloba and $P$. thonningii fruits. However, $\mathrm{YbPh}$ were strongly and positively correlated to the increase in cumulative gas production due to PEG for A. erubescens and A. nilotica. Folin-Ciocalteau assayed phenolics $(\mathrm{SPh})$ were not correlated to response to PEG in P. thonningii and A. sieberiana. It was concluded that the PEG effect on in vitro fermentation was closely related to some measures of phenolic concentration but the relationships varied with tree species.
\end{abstract}

Keywords: Colorimetric phenolic assays; in vitro tannin bioassays; tree fruits; correlation.

\#Corresponding author. E-mail: vmlambo@agric.uniswa.sz, victormlambo@yahoo.co.uk

${ }^{\#}$ Present address: Faculty of Agriculture, University of Swaziland, P.O. Luyengo, Swaziland.

\section{Introduction}

Recurrent droughts and low rainfall in semi-arid regions of Zimbabwe result in a poor supply of high quality animal feed and are causing a steady decline in livestock productivity on smallholder communal farms. As a result, livestock composition has changed over the years, with drought-tolerant goats playing a more prominent role in livelihoods of communal farmers. The Acacia thornveld is the main feed resource for goats in these semi-arid areas. Trees, especially those of the Acacia genus, are adapted to a low moisture environment (Timberlake et al., 1999) thus offer a reliable source of feed in the form of leaves and fruits. Many Acacias produce potentially nutritious fruits with up to 20\% crude protein (Tanner et al., 1990; Kibon \& Maina, 1993; Ncube \& Mpofu, 1994; Mlambo et al., 2008), which could be used to supplement low quality roughage in the long dry season. However, anti-nutritional factors, such as tannins, are known to be a significant component of many browse tree species (Aganga \& Mosase, 2001; Mlambo et al., 2008). When Acacia and other tree fruits are considered as potential protein supplements for ruminant livestock, knowledge on the concentration and biological activity of tannins is important as these may interfere with the digestion and metabolism of protein (Komolong et al., 2001). Reduced rumen protein degradability due to the presence of tannins limits the supply of rumen ammonia for microbial activity. This, in turn, negatively affects the utilisation of poor quality cereal crop residues which are a major component of ruminant livestock diets in semi-arid areas of Zimbabwe.

The isolation and quantification of total phenolics such as tannins in plants are important to nutritional and ecological studies (Tempel, 1982). Tannin quantification methods have been based on chemical and biochemical properties or capacity of the tannins to bind substrates (Waterman \& Mole, 1994). The effect of 
tannins on the nutritive value of forage is thought to depend on many factors including their concentration, molecular weight and chemical structure (McSweeney et al., 1999; Mueller-Harvey, 2006) all of which can affect the strength of tannin-nutrient complexes formed. Tannin contents are frequently used to determine the nutritive value of tanniniferous forages and these have been measured using colorimetric, gravimetric, protein precipitation methods and more recently, in vitro tannin bioassays. Colorimetric and gravimetric quantification procedures largely depend on the efficiency of the extraction process. However, unextractable tannins, which are tightly bound to fibre and/or protein, may be equally important because they may also affect digestion processes.

The in vitro bioassay of tannins entails incubating plant samples with rumen fluid in the presence or absence of a tannin-binding agent such as polyethylene glycol (PEG). The differences in fermentation characteristics of PEG-treated and untreated substrates provide information on the potential biological effects of tannins in rumen fermentation. This technique has the advantage that tannins are evaluated in situ (without the need for extraction) and therefore the total tannin biological activity against a microbial population is measured. The in vitro tannin bioassay, therefore, represents a useful and complementary approach to unravel the potential effects of tannins on rumen microbial function. The limitations of this method include the need to keep fistulated animals, initial cost of the equipment as well as running costs and that it is relatively time-consuming when compared to colorimetric and gravimetric assays. Polyethylene glycol has been used to inactivate tannins and thus neutralizes their negative effects on feed intake and digestibility in sheep, goats and cattle (Silanikove et al., 1994; Villalba \& Provenza, 2001; Ben Salem et al., 2002).

The objective of the study was, therefore, to investigate the relationship between the in vitro biological activity of tannins in tree fruits and their phenolic contents as measured by faster and relatively cheaper colorimetric and gravimetric assays. The hypothesis that strong positive relationships exist between the in vitro biological activities of tannins and the commonly used, rapid colorimetric and gravimetric assays of phenolic concentration was of interest. An in vitro gas production bioassay was used to assess the potential biological effect of tannins by incubating tree fruits with and without tannin-binding PEG.

\section{Material and Methods}

Mature and ripe fruit samples were harvested by hand from A. nilotica, A. erubescens, A. erioloba, $P$. thonningii, $D$. cinerea and $A$. sieberiana trees growing in the thornveld of Mbembeswana communal areas (red sialitic clay soils), about $100 \mathrm{~km}$ south-west of Matopos Research Station in Bulawayo, Zimbabwe (latitude - longitude: $20^{\circ} 23^{\prime} \mathrm{S}-28^{\circ} 28^{\prime} \mathrm{E}$, altitude $1340 \mathrm{~m}$ ). Annual rainfall in this area averages $400 \mathrm{~mm}$.

Fruits were collected from each of 10 randomly selected individual trees for each species within a one hectare plot and stored in khaki paper bags at room temperature. Collection methods ensured that all mature and dry fruits from each individual tree were harvested. For the analysis of neutral detergent fibre (NDF), acid detergent fibre (ADF), acid detergent insoluble $\mathrm{N}$ (ADIN) and lignin, fruits were ground to pass a $2 \mathrm{~mm}$ screen using a rotor mill (Fritsch Pulverisette 14, Glen Creston Ltd, Middlesex, UK) while for the analysis of total nitrogen $(\mathrm{N})$ and phenolics a $1 \mathrm{~mm}$ screen was used. Milled samples were stored in sealed containers at room temperature $\left(25^{\circ} \mathrm{C}\right)$ pending chemical analyses and in vitro fermentation.

The chemical analyses described below were carried out as part of an earlier study on the chemical composition and in vitro fermentation of tree fruits (Mlambo et al., 2008) and are summarised here for ease of reference in Tables 1 and 2 in order to describe the fruit materials used in this study. Chemical analyses data summarised in the two tables were used in their raw form for correlation analyses with in vitro tannin bioactivity reported in this paper.

Total N was determined using the Dumas total combustion method (AOAC, 1995; Method number 990.03). Neutral detergent fibre and ADF were determined according to Van Soest et al. (1991). Neutral detergent fibre was assayed without sodium sulphite but with a heat-stable $\alpha$-amylase due to the high levels of starch in the tree fruits. Both NDF and ADF were expressed without residual ash. Lignin was determined by oxidation of the acid detergent fibre fraction using potassium permanganate and estimated as the resultant loss in weight of the acid detergent fibre fraction. Acid detergent insoluble $\mathrm{N}$ was determined by $\mathrm{N}$ analysis of ADF, dried at $40{ }^{\circ} \mathrm{C}$ for $48 \mathrm{~h}$, using the Dumas total combustion method (AOAC, 1995; Method number 990.03) with a Carlo Erba Elemental Analyser 2100 (Elemental Microanalysis Ltd. Okehampton, UK).

Soluble phenolics (SPh) were estimated using the Folin-Ciocalteau method (Singleton \& Rossi, 1965), after extracting a $40 \mathrm{mg}$ sample three times $(5 \mathrm{~min}$ at a time) with $10 \mathrm{~mL}$ aqueous acetone $(7: 3 \mathrm{v} / \mathrm{v}$, acetone : water). Absorbance was measured using a spectrophotometer at $675 \mathrm{~nm}$. Gallic acid was used as a standard 
with the results expressed as gallic acid equivalents.

Samples $(40 \mathrm{mg})$ were extracted with aqueous acetone $(7: 3 \mathrm{v} / \mathrm{v}$, acetone:water) $(5 \mathrm{~mL})$ and the extract $(0.5 \mathrm{~mL})$ was assayed for soluble/extractable-condensed tannins (SCT) using the modified butanol-HCl iron inclusion method (Porter et al., 1986). Soluble condensed tannin concentration was reported as absorbance units (AU) at $550 \mathrm{~nm}$ per $40 \mathrm{mg}$ sample. Insoluble/unextractable-condensed tannin (ICT) content was similarly determined in the residue that remained after aqueous acetone extraction using the butanol- $\mathrm{HCl}$ reagent according to Terrill et al. (1992). Insoluble condensed tannin concentration was also reported as absorbance units (AU) at $550 \mathrm{~nm}$ per $40 \mathrm{mg}$ sample.

Table 1 Nitrogen $(\mathrm{N})$, acid detergent insoluble N (ADIN), neutral detergent fibre (NDF), acid detergent fibre $(\mathrm{ADF})$ and lignin $(\mathrm{g} / \mathrm{kg} \mathrm{DM} \pm$ s.e.) content of tree fruits (Mlambo et al., 2008)

\begin{tabular}{lccccc}
\hline Species & $\mathrm{N}$ & ADIN & aNDFom & ADFom & Lignin $^{1}$ \\
\hline D. cinerea & $19.9^{\mathrm{b}}$ & $5.7^{\mathrm{c}}$ & $441^{\mathrm{d}}$ & $269^{\mathrm{ab}}$ & $76.6^{\mathrm{b}} \pm 7.51$ \\
A. erioloba & $21.3^{\mathrm{b}}$ & $3.9^{\mathrm{ab}}$ & $415^{\mathrm{c}}$ & $298^{\mathrm{b}}$ & $45.4^{\mathrm{a}} \pm 6.13$ \\
A. erubescens & $27.1^{\mathrm{c}}$ & $6.7^{\mathrm{cd}}$ & $543^{\mathrm{f}}$ & $392^{\mathrm{bc}}$ & $114^{\mathrm{d}} \pm 6.13$ \\
A. nilotica & $14.7^{\mathrm{a}}$ & $7.8^{\mathrm{d}}$ & $236^{\mathrm{a}}$ & $178^{\mathrm{a}}$ & $46.8^{\mathrm{a}} \pm 6.13$ \\
P. thonningii & $13.5^{\mathrm{a}}$ & $4.2^{\mathrm{b}}$ & $493^{\mathrm{e}}$ & $400^{\mathrm{c}}$ & $90.9^{\mathrm{c}} \pm 6.13$ \\
A. sieberiana & $13.6^{\mathrm{a}}$ & $2.6^{\mathrm{a}}$ & $356^{\mathrm{b}}$ & $192^{\mathrm{a}}$ & $45.4^{\mathrm{a}} \pm 6.13$ \\
\hline s.e. of the mean & 0.71 & 0.69 & 7.5 & 49.2 & \\
\hline a,... In a column, means with different superscripts significantly differ at P $<0.05$. & \\
${ }^{1}$ For lignin, means are presented with their respective standard errors due to unequal replication caused by sample loss.
\end{tabular}

Table 2 Phenolic content (folin assayed soluble phenolics (SPh) (gallic acid equivalent $\mu \mathrm{g} / \mathrm{mg} \mathrm{DM}$ ), ytterbium precipitated phenolics ( $\mathrm{YbPh}, \mathrm{g} / \mathrm{kg} \mathrm{DM} \pm$ s.e.), soluble condensed tannins (SCT) $\left(\mathrm{AU}_{550 \mathrm{~nm}} / 40 \mathrm{mg}\right.$ $\mathrm{DM})$, and insoluble condensed tannins (ICT) $\left(\mathrm{AU}_{550 \mathrm{~mm}} / 40 \mathrm{mg} \mathrm{DM}\right)$ of tree fruits (Mlambo et al., 2008)

\begin{tabular}{|c|c|c|c|c|}
\hline Species & $\mathrm{SPh}$ & $\mathrm{YbPh}^{1}$ & $\mathrm{SCT}$ & ICT \\
\hline D. cinerea & $6.5^{c}$ & ND & $3.4^{\mathrm{e}}$ & $0.059^{\mathrm{c}}$ \\
\hline A. erioloba & $5.6^{\mathrm{b}}$ & $206^{\mathrm{a}} \pm 18.0$ & $0.7^{\mathrm{b}}$ & $0.032^{\mathrm{a}}$ \\
\hline A. erubescens & $1.4^{\mathrm{a}}$ & $175^{\mathrm{a}} \pm 14.7$ & $0.5^{\mathrm{a}}$ & $0.033^{\mathrm{a}}$ \\
\hline A. nilotica & $11.5^{\mathrm{d}}$ & $758^{d} \pm 14.7$ & $1.2^{\mathrm{c} 2}$ & $0.057^{\mathrm{c} 2}$ \\
\hline P. thonningii & $6.4^{c}$ & $299^{b} \pm 14.7$ & $4.1^{\mathrm{f}}$ & $0.308^{d}$ \\
\hline A. sieberiana & $5.6^{\mathrm{b}}$ & ND & $2.7^{\mathrm{d}}$ & $0.037^{\mathrm{b}}$ \\
\hline s.e. & 0.38 & & 0.04 & 0.0014 \\
\hline
\end{tabular}

Determination of ytterbium precipitable phenolics $(\mathrm{YbPh})$ was done using an aqueous acetone (7:3 v/v, acetone:water) extract, obtained as described above for SCT. The procedure was carried out according to Reed et al. (1985). Results were expressed as g YbPh/kg DM of sample. 
Rumen microbial fermentation was assessed in vitro using the Reading Pressure Technique (RPT, Mauricio et al., 1999). Rumen fluid was collected at 07:00, prior to feeding. The donor animal was a lactating cow not previously exposed to tanniniferous tree fruits that were offered a total mixed ration comprised of grass and maize silages $(60 \%)$ and a concentrate (wheat grain, barley grain and soya bean meal) (40\%) ad libitum. Rumen digesta samples from multiple sites within the rumen were hand-squeezed and the fluid collected in pre-warmed thermos flasks. These were transported to the fermentation laboratory and strained through two layers of warm muslin cloth. The resulting rumen fluid was held under carbon dioxide at $39^{\circ} \mathrm{C}$. About $1 \mathrm{~g}$ tree fruit sample, ground to pass a $2 \mathrm{~mm}$ sieve, was weighed into $125 \mathrm{~mL}$ serum bottles. Using an automatic dispenser (Jencons, Hemel Hemstead, England), $90 \mathrm{~mL}$ reduced buffer was added to each serum bottle. The buffer was divided in two, and PEG (Mr 4 600, Adrich Chemical Company, Inc. USA) dissolved in one set to give an application rate of $1 \mathrm{~g}$ PEG/g DM of substrate, based on work done by Makkar et al. (1995) and Salawu et al. (1997). Serum bottles without samples (blanks) were also included for each of the three withdrawal periods to allow correction for residual DM from rumen fluid and any direct effect of PEG on fermentation gas release. Substrates were incubated for $95 \mathrm{~h}$. After addition of buffer, the flasks were sealed and stored at room temperature $\left(20^{\circ} \mathrm{C}\right)$ before being transferred to the incubators, set at $39{ }^{\circ} \mathrm{C}, 8 \mathrm{~h}$ before inoculation with rumen fluid. The serum bottles were each inoculated with $10 \mathrm{~mL}$ of fluid and incubated at $39^{\circ} \mathrm{C}$ for the duration of the experiment (i.e. 95 h). Inoculation was complete within 60 min of fluid being prepared. The time between rumen fluid collection and the start of inoculation was 40 min. Fermentation flasks without samples (blanks) were included to allow correction for gas produced directly from rumen fluid. Serum bottles were withdrawn after 24, 48 and $95 \mathrm{~h}$ incubation to estimate extent of degradability.

Headspace gas pressure was measured at 2, 4, 6, 8, 10, 12, 15, 19, 24, 30, 36, 48, 72 and 95 h postinoculation using a pressure transducer interfaced with a computer. Gas pressure readings (psi) were converted to gas volume $(\mathrm{mL})$ using the relationship between gas pressure and gas volume determined for the site as:

$$
G p=0.18+3.697 P_{t}+0.0824 P_{t}^{2}
$$

where, $G_{p}=$ the predicted gas volume $(\mathrm{mL})$ and $P_{t}=$ the pressure transducer reading at time $\mathrm{t}(\mathrm{psi})$. Gas volume data were then fitted to the model of France et al. (1993):

$$
Y=A\left\{1-e^{[-b(t-T)-c(\sqrt{t}-\sqrt{T})]}\right\}
$$

where, $Y$ represents the cumulative gas production $(\mathrm{mL}), A$ is the asymptotic gas pool, $T$ is lag time (h) while $b\left(\mathrm{~h}^{-1}\right)$ and $c\left(\mathrm{~h}^{-0.5}\right)$ are decay rate constants. A combined fractional rate of gas production $(\mu)$ was calculated

$$
\text { as, } \mu=b+\frac{c \sqrt{t}}{2} \text {, where } t \text { is the incubation time. }
$$

In vitro DM degradability (iDMD) was determined by recovering the fermentation residues after 24 , 48 and $95 \mathrm{~h}$ of incubation by filtration through sintered-glass crucibles $(100-160 \mu \mathrm{m}$ porosity, Fisher Scientific, Loughbough, UK) under light vacuum. In vitro OM degradability (iOMD) was estimated by difference following ashing of the dried fermentation residues in a muffle furnace at $550{ }^{\circ} \mathrm{C}$ for $12 \mathrm{~h}$. Partition factors (PF, a measure of fermentation efficiency) were calculated at $48 \mathrm{~h}$ as:

[iOMD $(\mathrm{mg}) /$ cumulative gas production $(\mathrm{mL} / \mathrm{g} \mathrm{OM})]$.

A two-factor treatment arrangement in a completely randomised design was used with species and PEG as the main effects. Cumulative gas production, rate of gas production and in vitro organic matter degradability (iOMD) data were subjected to GLM procedures of SAS (1996) to test for differences due to species and PEG treatment. Treatment means were separated using the least significant difference (LSD) method. Pearson's correlation coefficients were used to establish the relationship between phenolic concentration (assayed by chemical and gravimetric assays (Mlambo et al., 2008)) and in vitro tannin effect.

\section{Results}

Table 3 shows the effect of including PEG during the in vitro incubation of tree fruits. Polyethylene glycol inclusion increased cumulative gas production of all substrates. The greatest response to PEG after $24 \mathrm{~h}$ incubation was found for $D$. cinerea fruit samples (an increase from 31 to $107.2 \mathrm{~mL}$ gas). The response to PEG treatment declined with incubation time for all tree species. 
Table 3 Effect of polyethylene glycol (PEG) treatment on the cumulative gas production $(\mathrm{mL})$ from fruit substrates at $6,12,24$ and $48 \mathrm{~h}$ post-inoculation

\begin{tabular}{|c|c|c|c|c|c|c|c|c|c|}
\hline \multirow{3}{*}{ Species } & \multicolumn{8}{|c|}{ Cumulative gas production (mL/g OM) } & \multirow{3}{*}{$\begin{array}{c}48 \text { h PEG } \\
\text { effect } \\
(\%)\end{array}$} \\
\hline & \multicolumn{2}{|c|}{$6 \mathrm{~h}$} & \multicolumn{2}{|c|}{$12 \mathrm{~h}$} & \multicolumn{2}{|c|}{$24 \mathrm{~h}$} & \multicolumn{2}{|c|}{$48 \mathrm{~h}$} & \\
\hline & 1 & ${ }^{2}+$ & - & + & - & + & - & + & \\
\hline D. cinerea & $2.90^{\mathrm{a}}$ & $31.2^{b}$ & $17.0^{\mathrm{a}}$ & $63.7^{b}$ & $31.1^{\mathrm{a}}$ & $107.2^{b}$ & $48.0^{\mathrm{a}}$ & $156.2^{b}$ & 225 \\
\hline A. erioloba & $27.5^{\mathrm{a}}$ & $37.9^{b}$ & $52.1^{\mathrm{a}}$ & $75.5^{b}$ & $86.4^{\mathrm{a}}$ & $121.0^{b}$ & $130.1^{\mathrm{a}}$ & $163.9^{b}$ & 26.2 \\
\hline A. erubescens & $15.7^{\mathrm{a}}$ & $21.2^{b}$ & $39.6^{\mathrm{a}}$ & $49.6^{b}$ & $72.5^{\mathrm{a}}$ & $86.3^{b}$ & $102.3^{\mathrm{a}}$ & $115.1^{b}$ & 12.7 \\
\hline A. nilotica & $11.0^{\mathrm{a}}$ & $34.3^{b}$ & $27.8^{\mathrm{a}}$ & $63.8^{b}$ & $48.6^{\mathrm{a}}$ & $102.3^{b}$ & $78.8^{\mathrm{a}}$ & $150.0^{b}$ & 90.4 \\
\hline P. thonningii & $23.9^{\mathrm{a}}$ & $48.5^{b}$ & $50.9^{\mathrm{a}}$ & $115.0^{\mathrm{b}}$ & $97.7^{\mathrm{a}}$ & $163.9^{b}$ & $143.1^{\mathrm{a}}$ & $193.3^{b}$ & 35.0 \\
\hline A. sieberiana & $15.0^{\mathrm{a}}$ & $37.8^{\mathrm{b}}$ & $43.5^{\mathrm{a}}$ & $80.9^{b}$ & $72.6^{\mathrm{a}}$ & $142.4^{b}$ & $130.2^{\mathrm{a}}$ & $197.8^{b}$ & 52.3 \\
\hline s.e. & \multicolumn{2}{|c|}{1.83} & \multicolumn{2}{|c|}{2.39} & \multicolumn{2}{|c|}{3.03} & \multicolumn{2}{|c|}{3.74} & \\
\hline
\end{tabular}

${ }^{\mathrm{a}, \mathrm{b}}$ Within incubation time and species, means with different superscripts significantly differ at $\mathrm{P}<0.05$.

${ }^{1}$ Incubated without polyethylene glycol; ${ }^{2}$ Incubated with polyethylene glycol.

Polyethylene glycol enhanced $(\mathrm{P}<0.05)$ rate of gas production, as shown in Table 4, with the greatest increase observed between $4-6 \mathrm{~h}$ post-incubation for $D$. cinerea fruits. In contrast, A. erioloba and P. thonningii fruits showed greater responses to PEG treatment after $12 \mathrm{~h}$ incubation.

Table 4 The response of rate of gas production $(\mathrm{mL} / \mathrm{h})$ from fruit substrates to PEG treatment $(-/+)$ between $4-6,10-12,19-24$ and $36-48$ h post-incubation

\begin{tabular}{|c|c|c|c|c|c|c|c|c|c|}
\hline \multirow{3}{*}{ Species } & \multicolumn{8}{|c|}{ Rate of gas production $(\mathrm{mL} / \mathrm{h})$} & \multirow{3}{*}{$\begin{array}{c}48 \text { h PEG } \\
\text { effect } \\
(\%)\end{array}$} \\
\hline & \multicolumn{2}{|c|}{$4-6 h$} & \multicolumn{2}{|c|}{$10-12 \mathrm{~h}$} & \multicolumn{2}{|c|}{$19-24 \mathrm{~h}$} & \multicolumn{2}{|c|}{$36-48 \mathrm{~h}$} & \\
\hline & T- & ${ }^{2}+$ & - & + & - & + & - & + & \\
\hline D. cinerea & $0.9^{\mathrm{a}}$ & $6.5^{b}$ & $3.1^{\mathrm{a}}$ & $5.0^{\mathrm{b}}$ & $0.9^{\mathrm{a}}$ & $3.1^{\mathrm{b}}$ & $0.4^{\mathrm{a}}$ & $1.5^{\mathrm{b}}$ & 275.0 \\
\hline A. erioloba & $5.3^{\mathrm{a}}$ & $6.7^{\mathrm{b}}$ & $4.0^{\mathrm{a}}$ & $6.0^{\mathrm{b}}$ & $2.9^{\mathrm{a}}$ & $3.2^{b}$ & $1.4^{\mathrm{a}}$ & $1.3^{\mathrm{a}}$ & 0 \\
\hline A. erubescens & $3.2^{\mathrm{a}}$ & $3.8^{\mathrm{b}}$ & $4.2^{\mathrm{a}}$ & $5.0^{b}$ & $2.5^{\mathrm{a}}$ & $2.6^{\mathrm{a}}$ & $0.7^{\mathrm{a}}$ & $0.7^{\mathrm{a}}$ & 0 \\
\hline A. nilotica & $2.7^{\mathrm{a}}$ & $7.0^{b}$ & $2.5^{\mathrm{a}}$ & $4.8^{b}$ & $1.8^{\mathrm{a}}$ & $2.8^{b}$ & $1.1^{\mathrm{a}}$ & $1.7^{\mathrm{b}}$ & 54.5 \\
\hline P. thonningii & $4.7^{\mathrm{a}}$ & $10.7^{b}$ & $4.2^{\mathrm{a}}$ & $10.0^{b}$ & $4.3^{\mathrm{a}}$ & $2.8^{b}$ & $0.9^{\mathrm{a}}$ & $0.6^{\mathrm{b}}$ & -33.3 \\
\hline A. sieberiana & $3.6^{\mathrm{a}}$ & $7.8^{b}$ & $4.4^{\mathrm{a}}$ & $7.0^{b}$ & $1.9^{\mathrm{a}}$ & $4.1^{b}$ & $2.4^{\mathrm{a}}$ & $1.6^{\mathrm{b}}$ & -33.3 \\
\hline s.e. & \multicolumn{2}{|c|}{0.28} & \multicolumn{2}{|c|}{0.20} & \multicolumn{2}{|c|}{0.10} & \multicolumn{2}{|c|}{0.05} & \\
\hline
\end{tabular}

A comparison of gas release kinetics from these fruits shows that $D$. cinerea gave the highest response to PEG. Table 5 presents the effect of PEG treatment on gas production parameters which have been fitted using the France model (France et al., 1993). Tannin inactivation through PEG increased $(\mathrm{P}<0.05)$ the asymptotic gas pool $(A)$ in all tree fruits except for $A$. erubescens fruits. Polyethylene glycol treatment significantly reduced time to half asymptote (T/2) for all samples except for A. erubescens and A. erioloba fruits. Fractional rate of gas production $(\mu, \% / \mathrm{h})$ at $12 \mathrm{~h}$ post-inoculation was increased due to PEG treatment for A. sieberiana, $P$. thonningii and A. nilotica. Polyethylene glycol treatment reduced the length of the lag phase in fruits from $D$. cinerea, A. nilotica, $P$. thonningii and A. sieberiana. Surprisingly, an increased lag phase was observed in A. erioloba fruit. 
Table 5 Effect of polyethylene glycol (PEG) treatment on fitted gas production parameters, A (asymptotic gas pool, $\mathrm{mL} / \mathrm{g} \mathrm{OM}$ ), $L$ (lag time, $\mathrm{h}$ ), $T / 2$ (time to half asymptote, $\mathrm{h}$ ), $t$ (incubation time, $\mathrm{h}$ ) and $\mu$ (fractional rate of gas production, $\% / \mathrm{h}$ ), estimated using the France et al. (1993) model

\begin{tabular}{|c|c|c|c|c|c|c|c|c|}
\hline \multirow{3}{*}{ Species } & \multicolumn{8}{|c|}{ Parameters } \\
\hline & \multicolumn{2}{|c|}{$A$} & \multicolumn{2}{|c|}{$L$} & \multicolumn{2}{|c|}{$T / 2$} & \multicolumn{2}{|c|}{$\mu$ at $t=12$} \\
\hline & ${ }^{1}-$ & ${ }^{2}+$ & - & + & - & + & - & + \\
\hline D. cinerea & $61.2^{\mathrm{a}}$ & $187^{\mathrm{b}}$ & $3.6^{\mathrm{a}}$ & $1.3^{b}$ & $24.1^{\mathrm{a}}$ & $20.8^{\mathrm{b}}$ & $3.4^{\mathrm{a}}$ & $3.5^{\mathrm{a}}$ \\
\hline A. erioloba & $162^{\mathrm{a}}$ & $202^{\mathrm{b}}$ & $0.7^{\mathrm{a}}$ & $1.4^{\mathrm{b}}$ & $23.2^{\mathrm{a}}$ & $20.2^{\mathrm{a}}$ & $3.1^{\mathrm{a}}$ & $3.5^{\mathrm{a}}$ \\
\hline A. erubescens & $113^{\mathrm{a}}$ & $121^{\mathrm{a}}$ & $1.2^{\mathrm{a}}$ & $1.1^{\mathrm{a}}$ & $18.2^{\mathrm{a}}$ & $17.3^{\mathrm{a}}$ & $4.6^{\mathrm{a}}$ & $4.8^{\mathrm{a}}$ \\
\hline A. nilotica & $137^{\mathrm{a}}$ & $209^{b}$ & $1.7^{\mathrm{a}}$ & $1.0^{\mathrm{b}}$ & $43.6^{\mathrm{a}}$ & $26.6^{\mathrm{b}}$ & $1.7^{\mathrm{a}}$ & $2.6^{b}$ \\
\hline P. thonningii & $156^{\mathrm{a}}$ & $192^{\mathrm{b}}$ & $1.9^{\mathrm{a}}$ & $1.1^{\mathrm{b}}$ & $18.6^{\mathrm{a}}$ & $11.0^{\mathrm{b}}$ & $4.5^{\mathrm{a}}$ & $8.5^{b}$ \\
\hline A. sieberiana & $181^{\mathrm{a}}$ & $214^{\mathrm{b}}$ & $1.7^{\mathrm{a}}$ & $0.6^{\mathrm{b}}$ & $30.6^{\mathrm{a}}$ & $18.0^{\mathrm{b}}$ & $2.4^{\mathrm{a}}$ & $4.4^{b}$ \\
\hline s.e. & \multicolumn{2}{|c|}{15.9} & \multicolumn{2}{|c|}{0.62} & \multicolumn{2}{|c|}{3.01} & \multicolumn{2}{|c|}{0.51} \\
\hline
\end{tabular}

${ }^{\mathrm{a}, \mathrm{b}}$ Within incubation time and species, means with different superscripts significantly differ at $\mathrm{P}<0.05$.

${ }^{1}$ Incubated without polyethylene glycol; ${ }^{2}$ Incubated with polyethylene glycol.

In vitro organic matter degradability measurements at $24 \mathrm{~h}$ post-incubation varied widely between tree species (Table 6$)$. Polyethylene glycol increased $(\mathrm{P}<0.05) 24 \mathrm{~h}$ degradability of $A$. erubescens fruits but had no effect on 48 h degradability.

However, PEG treatment increased degradability of all the other fruit substrates. A comparison of $24 \mathrm{~h}$ degradability of samples across tree species showed that $A$. sieberiana fruits had the highest response to PEG treatment followed by A. erioloba, while at $48 \mathrm{~h}$ post-inoculation A. nilotica fruits gave the highest response to PEG treatment. Polyethylene glycol treatment reduced $(\mathrm{P}<0.05)$ degradability of $P$. thoningii fruits at $48 \mathrm{~h}$. Polyethylene glycol treatment reduced $(\mathrm{P}<0.05) \mathrm{PF}$ values for all tree fruits (Table 7) at both 24 and $48 \mathrm{~h}$ incubation times. A comparison of fruits showed that the biggest response was from $D$. cinerea followed by $A$. nilotica and $P$. thonningii while $A$. erubescens and A. erioloba gave the smallest response.

Table 8 shows Pearson's correlation coefficients for linear relationships between various phenolic concentrations and PEG effect as measured by the increase in cumulative gas production. For $D$. cinerea species, colorimetric assays were poorly $(\mathrm{P}>0.05)$ correlated to increases in gas production due to $\mathrm{PEG}$

Table 6 Effect of polyethylene glycol (PEG) treatment on the organic matter degradability $(\mathrm{mg} / \mathrm{g} \mathrm{OM})$ of whole fruit substrate at 24 and $48 \mathrm{~h}$ post-incubation

\begin{tabular}{|c|c|c|c|c|c|}
\hline \multirow{3}{*}{ Species } & \multicolumn{4}{|c|}{ Organic matter degradability } & \multirow{3}{*}{$\begin{array}{c}48 \text { h PEG } \\
\text { effect } \\
(\%)\end{array}$} \\
\hline & \multicolumn{2}{|c|}{$24 \mathrm{~h}$} & \multicolumn{2}{|c|}{$48 \mathrm{~h}$} & \\
\hline & 1 & ${ }^{2}+$ & - & + & \\
\hline D. cinerea & $344^{\mathrm{a}}$ & $393^{b}$ & $372^{\mathrm{a}}$ & $482^{b}$ & 29.6 \\
\hline A. erioloba & $424^{\mathrm{a}}$ & $522^{b}$ & $541^{\mathrm{a}}$ & $595^{\mathrm{b}}$ & 10.0 \\
\hline A. erubescens & $419^{a}$ & $440^{b}$ & $493^{\mathrm{a}}$ & $500^{\mathrm{a}}$ & 1.4 \\
\hline A. nilotica & $598^{\mathrm{a}}$ & $678^{b}$ & $617^{\mathrm{a}}$ & $760^{\mathrm{b}}$ & 23.2 \\
\hline P. thonningii & $438^{\mathrm{a}}$ & $473^{b}$ & $557^{\mathrm{a}}$ & $501^{\mathrm{b}}$ & -10.1 \\
\hline A. sieberiana & $408^{\mathrm{a}}$ & $570^{b}$ & $621^{\mathrm{a}}$ & $670^{\mathrm{b}}$ & 7.9 \\
\hline s.e. & \multicolumn{2}{|c|}{7.2} & \multicolumn{2}{|c|}{7.3} & \\
\hline
\end{tabular}

${ }^{\mathrm{a}, \mathrm{b}}$ Within incubation time and species, means with different superscripts significantly differ at $\mathrm{P}<0.05$.

${ }^{1}$ Incubated without polyethylene glycol; ${ }^{2}$ Incubated with polyethylene glycol. 
Table 7 Effect of polyethylene glycol (PEG) treatment on partition factors (mg OMD/mL gas produced) of whole fruit substrate at 24 and $48 \mathrm{~h}$ post-incubation

\begin{tabular}{|c|c|c|c|c|c|}
\hline \multirow[b]{3}{*}{ Species } & \multicolumn{4}{|c|}{ Partition factor } & \multirow{3}{*}{$\begin{array}{l}48 \text { h PEG } \\
\text { effect ( } \%\end{array}$} \\
\hline & \multicolumn{2}{|c|}{$24 \mathrm{~h}$} & \multicolumn{2}{|c|}{$48 \mathrm{~h}$} & \\
\hline & 1 & ${ }^{2}+$ & - & + & \\
\hline D. cinerea & $11.4^{\mathrm{a}}$ & $3.6^{\mathrm{b}}$ & $8.0^{\mathrm{a}}$ & $3.1^{\mathrm{b}}$ & -61.3 \\
\hline A. erioloba & $4.8^{\mathrm{a}}$ & $4.2^{\mathrm{b}}$ & $4.1^{\mathrm{a}}$ & $3.6^{\mathrm{b}}$ & -12.2 \\
\hline A. erubescens & $5.9^{\mathrm{a}}$ & $5.0^{\mathrm{b}}$ & $4.9^{\mathrm{a}}$ & $4.3^{\mathrm{b}}$ & -12.2 \\
\hline A. nilotica & $11.7^{\mathrm{a}}$ & $6.4^{\mathrm{b}}$ & $7.6^{\mathrm{a}}$ & $4.9^{\mathrm{b}}$ & -35.5 \\
\hline P. thonningii & $4.7^{\mathrm{a}}$ & $2.9^{\mathrm{b}}$ & $4.0^{\mathrm{a}}$ & $2.6^{\mathrm{b}}$ & -35.0 \\
\hline A. sieberiana & $5.5^{\mathrm{a}}$ & $4.0^{\mathrm{b}}$ & $4.6^{\mathrm{a}}$ & $3.4^{\mathrm{b}}$ & -26.1 \\
\hline s.e. & & & & & \\
\hline
\end{tabular}

${ }^{\mathrm{a}, \mathrm{b}}$ Within incubation time and species, means with different superscripts significantly differ at $\mathrm{P}<0.05$.

${ }^{1}$ Incubated without polyethylene glycol; ${ }^{2}$ Incubated with polyethylene glycol.

treatment. For D. cinerea none of the Pearson's correlation coefficients were significant. Ytterbium precipitable phenolics $(\mathrm{YbPh})$ were poorly correlated with response to PEG for A. erioloba and P. thonningii fruits. However, $\mathrm{YbPh}$ were strongly and positively correlated to the increase in cumulative gas production due to PEG for A. erubescens and A. nilotica. Folin-Ciocalteau assayed total soluble phenolics (SPh) were not significantly correlated to the response to PEG in $P$. thonningii and A. sieberiana. However, $\mathrm{SPh}$ were positively correlated to the response to PEG in A. erubescens and A. nilotica, while a significant $(\mathrm{P}<0.05)$ correlation was demonstrated with A. erioloba 6 and $48 \mathrm{~h}$ post-incubation.

Soluble condensed tannins (SCT) were positively correlated to the PEG mediated increase in gas production in all fruits except $D$. cinerea. Insoluble condensed tannins (ICT) were positively correlated to the change in gas production due to PEG in all tree species except for $D$. cinerea and $P$. thoningii.

Pearson's correlation coefficients for relationships between phenolic concentrations and gas production kinetic responses due to PEG treatment are shown in Table 9. There was no significant correlation between $\mathrm{YbPh}$ content and increase in rate of gas production for $P$. thonningii, while significant $(\mathrm{P}<0.05)$ and positive correlations were obtained for A. erioloba ( $24 \mathrm{~h}$ post-incubation), A. erubescens and A. nilotica $(6,12$ and $48 \mathrm{~h}$ post-incubation). $\mathrm{SPh}$ were positively correlated to increase in rate of gas production in A. erubescens (6 h), A. nilotica $(6,12,48 \mathrm{~h})$ and A. sieberiana (48 h).

No significant relationship was observed between $\mathrm{SPh}$ content and rate of gas production in A. erioloba and $P$. thoningii fruits. SCT were poorly correlated to the rate of gas production for $D$. cinerea and A. erioloba, while relationship was positive for A. erubescens, A. nilotica $(6,12,48 \mathrm{~h})$, P. thoningii (6 and $48 \mathrm{~h}$ ) and $A$. sieberiana (6 and $12 \mathrm{~h})$.

\section{Discussion}

Results from this study show that tannins limit in vitro fermentation of tree fruits, thus the increase in gas production following inclusion of PEG provides a measure of potential effects of tannins on nutrient degradability (McSweeney et al., 1999). The use of PEG in this study demonstrated nutritional significance of tannins and provided a measure of potential fermentation of tree fruits in the absence of tannins. Measurements of cumulative gas production at 24 and $48 \mathrm{~h}$ post-inoculation were used for comparisons since it is likely that complete rumen fermentation occurs within $24-48 \mathrm{~h}$ of consumption in ruminant animals. Dichrostachys cinerea fruits gave the highest response to PEG supplementation in terms of both cumulative and rate of gas production suggesting that its tannins are more biologically active. The least response to PEG inclusion was observed in A. erubescens fruit. This can be attributed to its lower phenolic content and higher fibre and lignin content (Table 1) compared to the other tree fruits. Polyethylene glycol treatment removes the tannin inhibition on fermentation and thus more gas is released earlier resulting in higher rates of gas 
Table 8 A Pearson's correlation coefficient matrix for linear relationships between phenolic concentrations and increase in cumulative gas production due to tannin inactivation by polyethylene glycol at $6,12,24$ and $48 \mathrm{~h}$ post-incubation

\begin{tabular}{|c|c|c|c|c|c|}
\hline \multirow{2}{*}{ Species } & \multirow{2}{*}{ Incubation time $(\mathrm{h})$} & \multicolumn{4}{|c|}{ Phenolic concentration } \\
\hline & & $\mathrm{SCT}^{1}$ & $\mathrm{YbPh}^{2}$ & $\mathrm{SPh}^{3}$ & $\mathrm{ICT}^{4}$ \\
\hline \multirow{4}{*}{ D. cinerea } & 6 & -0.99 & ND & 0.20 & -0.84 \\
\hline & 12 & -0.98 & ND & 0.33 & -0.91 \\
\hline & 24 & -0.99 & ND & 0.30 & -0.90 \\
\hline & 48 & -0.98 & ND & -0.06 & -0.68 \\
\hline \multirow{4}{*}{ A. erioloba } & 6 & $0.78 * *$ & 0.32 & $0.74 *$ & $0.77 * *$ \\
\hline & 12 & $0.68^{*}$ & 0.56 & 0.48 & -0.54 \\
\hline & 24 & 0.39 & 0.23 & 0.24 & -0.32 \\
\hline & 48 & $0.82 * *$ & -0.38 & $0.90 * * *$ & $0.89 * * *$ \\
\hline \multirow{4}{*}{ A. erubescens } & 6 & $0.93 * * *$ & $0.92 * * *$ & $0.92 * * *$ & $0.94 * * *$ \\
\hline & 12 & $0.97 * * *$ & $0.98 * * *$ & $0.76^{*}$ & $0.97 * * *$ \\
\hline & 24 & $0.97 * * *$ & $0.98 * * *$ & $0.75 *$ & $0.96 * * *$ \\
\hline & 48 & $0.95 * * *$ & $0.95 * * *$ & $0.80 * *$ & $0.96 * * *$ \\
\hline \multirow{4}{*}{ A. nilotica } & 6 & $0.87 * *$ & $0.79 *$ & $0.77 * *$ & $0.91 * * *$ \\
\hline & 12 & $0.90 * * *$ & $0.81 * *$ & $0.81 * *$ & $0.94 * * *$ \\
\hline & 24 & $0.89 * * *$ & $0.79 *$ & $0.77 * *$ & $0.93 * * *$ \\
\hline & 48 & $0.90 * * *$ & $0.80 *$ & $0.78 * *$ & $0.93 * * *$ \\
\hline \multirow{4}{*}{ P. thonningii } & 6 & $0.76^{*}$ & 0.34 & -0.29 & -0.36 \\
\hline & 12 & $0.70 *$ & 0.37 & -0.26 & -0.43 \\
\hline & 24 & $0.71 *$ & 0.38 & -0.21 & -0.41 \\
\hline & 48 & $0.82 * *$ & 0.44 & -0.37 & -0.34 \\
\hline \multirow{4}{*}{ A. sieberiana } & 6 & $0.96^{* * *}$ & ND & 0.48 & $0.92 * * *$ \\
\hline & 12 & $0.92 * * *$ & ND & 0.38 & $0.85 * *$ \\
\hline & 24 & $0.90 * * *$ & ND & 0.34 & $0.85 * *$ \\
\hline & 48 & $0.68^{*}$ & ND & 0.57 & $0.69 *$ \\
\hline
\end{tabular}

Level of significance: ${ }^{*} 0.05,{ }^{* *} 0.01,{ }^{* * *} 0.001$.

${ }^{1} \mathrm{SCT}=$ soluble condensed tannins assayed by butanol- $\mathrm{HCl}$ reagent.

${ }^{2} \mathrm{YbPh}=$ total soluble phenolics assayed gravimetrically using trivalent ytterbium.

${ }^{3} \mathrm{SPh}=$ total soluble phenolics assayed by Folin-Ciocalteau reagent.

${ }^{4} \mathrm{ICT}=$ insoluble condensed tannins assayed by butanol- $\mathrm{HCl}$ reagent on extraction residue.

${ }^{5} \mathrm{ND}=\mathrm{YbPh}$ not determined.

production. This is confirmed by reduced lag times $(L)$ and shorter times to half asymptote $(T / 2)$ with some of the PEG-treated fruits. The inclusion of PEG, therefore, appears to offer a good measure of negative effect that tannins have on microbial fermentation. Although this in vitro tannin bioassay provides a method with which biological activity of tannins can be measured, it does not provide information on effects of nontannin phenolics. It is likely that non-tannin phenolics, which are not bound by PEG, will be left to negatively affect the microbial activity of the fermentation medium. There is evidence that low molecular weight phenolics, which do not participate in complexation reactions (thus are unlikely to be bound by PEG), can still interfere with nutrient absorption post-ruminally and nutrient metabolism in animal tissues (Waghorn et al., 1994b; Getachew et al., 2000a).

Degradability for tanniniferous forages is confounded by water-soluble phenolics, which cause an overestimation of iOMD as reported by Mlambo et al. (2008). Although there were increases in degradability in response to PEG treatment, these did not match the magnitude of increases in gas production. Indeed, at $48 \mathrm{~h}$, PEG treatment reduced the degradability value of $P$. thoningii fruits despite increasing cumulative gas 
Table 9 A Pearson's correlation coefficient matrix for linear relationships between phenolic concentrations and increase in rate of gas production in response to tannin inactivation by polyethylene glycol at $6,12,24$ and $48 \mathrm{~h}$ post-incubation

\begin{tabular}{|c|c|c|c|c|c|}
\hline \multirow[b]{2}{*}{ Species } & \multirow[b]{2}{*}{ Incubation time $(\mathrm{h})$} & \multicolumn{4}{|c|}{ Phenolic concentration } \\
\hline & & $\mathrm{SCT}^{1}$ & $\mathrm{YbPh}^{2}$ & $\mathrm{SPh}^{3}$ & $\mathrm{ICT}^{4}$ \\
\hline \multirow[t]{4}{*}{ D. cinerea } & $4-6$ & -0.94 & $\mathrm{ND}$ & 0.45 & -0.97 \\
\hline & $10-12$ & 0.61 & ND & -0.86 & 0.95 \\
\hline & $19-24$ & 0.10 & ND & -0.99 & 0.65 \\
\hline & $36-48$ & -0.22 & ND & -0.94 & 0.38 \\
\hline \multirow[t]{4}{*}{ A. erioloba } & $4-6$ & 0.63 & 0.42 & 0.52 & -0.55 \\
\hline & 10- 12 & -0.12 & 0.45 & -0.32 & 0.28 \\
\hline & $19-24$ & 0.52 & $0.78^{*}$ & 0.26 & -0.35 \\
\hline & $36-48$ & -0.85 & -0.70 & -0.66 & $0.74 *$ \\
\hline \multirow[t]{4}{*}{ A. erubescens } & $4-6$ & $0.96^{* * *}$ & $0.97 * * *$ & $0.68^{*}$ & $0.96^{* * *}$ \\
\hline & $10-12$ & $0.94 * * *$ & $0.97 * * *$ & 0.62 & $0.93 * * *$ \\
\hline & $19-24$ & $0.96^{* * *}$ & $0.98^{* * *}$ & 0.61 & $0.94 * * *$ \\
\hline & $36-48$ & $0.89 * * *$ & $0.90^{* * *}$ & -0.64 & $0.87 * * *$ \\
\hline \multirow[t]{4}{*}{ A. nilotica } & $4-6$ & $0.86^{* *}$ & $0.73^{*}$ & $0.74 *$ & $0.93 * * *$ \\
\hline & $10-12$ & $0.77^{*}$ & $0.70^{*}$ & $0.66^{*}$ & $0.81 * *$ \\
\hline & $19-24$ & 0.42 & 0.39 & 0.44 & 0.43 \\
\hline & $36-48$ & $0.87^{* *}$ & $0.76^{*}$ & $0.74 *$ & $0.87 * *$ \\
\hline \multirow[t]{4}{*}{ P. thonningii } & $4-6$ & $0.78^{* *}$ & 0.34 & -0.30 & -0.33 \\
\hline & $10-12$ & -0.11 & 0.21 & 0.23 & -0.53 \\
\hline & $19-24$ & -0.37 & 0.22 & 0.17 & -0.42 \\
\hline & $36-48$ & $0.96^{* * *}$ & 0.43 & -0.56 & -0.16 \\
\hline \multirow[t]{4}{*}{ A. sieberiana } & $4-6$ & $0.95^{* * *}$ & ND & 0.52 & $0.84 * *$ \\
\hline & $10-12$ & $0.86^{* *}$ & ND & -0.57 & -0.07 \\
\hline & $19-24$ & 0.07 & ND & -0.28 & -0.53 \\
\hline & $36-48$ & 0.50 & ND & $0.68^{*}$ & $0.86^{* *}$ \\
\hline
\end{tabular}

Level of significance: ${ }^{*} 0.05,{ }^{* *} 0.01,{ }^{* * *} 0.001$.

${ }^{1} \mathrm{SCT}=$ soluble condensed tannins assayed by butanol-HCl reagent.

${ }^{2} \mathrm{YbPh}=$ total soluble phenolics assayed gravimetrically using trivalent ytterbium.

${ }^{3} \mathrm{SPh}=$ total soluble phenolics assayed by Folin-Ciocalteau reagent.

${ }^{4} \mathrm{ICT}=$ insoluble condensed tannins assayed by butanol- $\mathrm{HCl}$ reagent on extraction residue.

${ }^{5} \mathrm{ND}=\mathrm{YbPh}$ not determined.

production at the same time. Makkar et al. (1995) and Jones et al. (2000) reported that the presence of insoluble PEG-tannin complexes in fermentation residues could lead to underestimation of degradability measurements. PEG-tannin complexes are known to be insoluble in boiling water, neutral and acid detergent as well as many organic solvents (Jones, 1965; Jones \& Mangan, 1977). Thus, without information on the protein degradability response to PEG supplementation, the tannin bioassay does not provide adequate information on the potential of tree fruits as protein supplements. The use of ${ }^{14} \mathrm{C}$-labelled PEG to estimate corrected degradability (Jones \& Palmer, 2000) is too expensive or inappropriate, for safety reasons, in most laboratories in developing countries. The determination of degradability of nitrogen, instead of DM, is unlikely to be affected by PEG-tannin complexes (Jones et al., 2000) and thus can be used as a measure of the effect of PEG on degradability of tanniniferous forages, especially tree fruits which can provide protein to animals feeding on poor quality fibrous forages. Polyethylene glycol treatment reduced fermentation efficiency as evidenced by the lower partition factors (PF) calculated as the amount of organic matter degraded relative to the volume of gas produced. Large PF values obtained for D. cinerea and A. nilotica 
early in the incubation period could have been the result of phenolics losses, measured as degraded substrate or reduced fermentation of soluble fractions due to the presence of phenolics in the fermentation medium (Baba et al., 2002). By substantially increasing gas release from tree fruits and causing small increases in iOMD, PEG treatment effectively depressed partition factors, in agreement with the findings of Baba et al. (2002). Thus the reduction in PF values in response to PEG treatment in this study can be attributed to the associated increase in gas production, although there is also evidence that PEG treatment decreases the efficiency of microbial protein synthesis (Makkar et al., 1999). Tannins may be able to partition nutrients so that a higher proportion of degraded substrate is channelled to microbial protein synthesis rather than to the production of short-chain fatty acids (SCFA) and fermentation gases. Presumably, this scenario only exists when the level and biological activity of tannins in the rumen allows for normal microbial function. The limitation of this in vitro tannin bioassay is that it only simulates rumen function and possibly highlights the negative biological effects of tannins. It is known that certain tannins can increase ruminal escape protein which is beneficial to ruminant animals. Indeed, Mlambo et al. (2004) reported that protein retention was higher when untreated tanniniferous $D$. cinerea fruits were fed to goats in a metabolism trial and that PEGtreatment lowered protein retention in the same study. This indicates that the tannins' in vitro negative effects may not be reproduced in vivo, suggesting that the PEG-based in vitro bioassay could be a poor predictor of in vivo biological effects of tannins.

A PEG effect on in vitro fermentation is closely related to some measures of phenolic concentration. However, the relationships varied with tree species and chemical assays. Tannins are known to be chemically diverse polyphenolic compounds with variable biological activities (Hagerman \& Butler, 1989). This is clearly demonstrated by $D$. cinerea fruits $(\mathrm{SPh}=6.5 \mathrm{GAE} \mu \mathrm{g} / \mathrm{mg} \mathrm{DM})$ showing higher fermentation responses to PEG compared to A. nilotica fruits ( $\mathrm{SPh}=11.5 \mathrm{GAE} \mu \mathrm{g} / \mathrm{mg} \mathrm{DM})$. Acacia nilotica tannins (i.e. low molecular weight flavanol gallates) are structurally different from $D$. cinerea tannins (i.e. condensed tannins) (Ayoub, 1985; Self et al., 1986), which is probably why their responses to PEG treatment differ markedly. In addition, D. cinerea and P. thonningii fruits have similar amounts of SPh and SCT (Table 2), yet only P. thonningii fruits SCT had a significant positive correlation with both increase in cumulative and increase in rate of gas production. For $D$. cinerea fruits, none of the measures of phenolic concentration investigated were related to biological activity of tannins as measured by cumulative gas production and kinetic responses. Khazaal \& Ørskov (1994) also observed that several tannin concentration estimates were poorly correlated with changes in gas production after treating tanniniferous forages with polyvinyl pyrrolidone, which is another tannin-binding polymer.

The positive correlations between PEG effect on both cumulative and rate of gas production and SCT, $\mathrm{YbPh}$ and $\mathrm{SPh}$ for $A$. erubescens and A. nilotica suggest that these chemical assays can be used as predictive tools for biological activity of tannins in these two species. However, we are in agreement with Vitti et al. (2005) who concluded that tannin concentration is a poor predictor of biological activity of tannins. The PEG-based in vitro tannin bioassay complements the chemical methods because it specifically highlights the presence of potentially active tannins. The use of the RPT as an in vitro tannin bioassay should present few technical problems to laboratories in developing countries. However, where funds are not available for the purchasing of the equipment, it appears that the SCT colorimetric assay could be used to screen forage as well as to predict biological activity of tannins.

\section{Conclusions}

None of the rapid chemical phenolic assays, apart from SCT, had consistent relationships with the in vitro tannin bioassay across the tree species. The chemical assays are still important where screening of forage is to be undertaken as the methods are useful in establishing the presence or absence of phenolics. Phenolic concentration estimated through chemical assays relate well to biological activity of tannins in fruits from all tree species except $D$. cinerea and $P$. thoningii. The PEG-based in vitro bioassay assessed the potential biological effects of tannins and confirmed that Acacia and other tree fruits contain biologically active tannins, which may limit their utilisation as protein supplements. With an increase of $225 \%$ in cumulative gas production after PEG treatment, $D$. cinerea fruits had the most biologically active tannins in vitro. 


\section{Acknowledgements}

This publication is an output from a research project (R7351, Livestock Production Programme) funded by the United Kingdom Department for International Development (DFID) for the benefit of developing countries. The views expressed are not necessarily those of DFID.

\section{References}

Aganga, A.A. \& Mosase, K.W., 2001. Tannin content, nutritive value and dry matter digestibility of Lonchocarpus capassa, Zizyphus mucronata, Sclerocarya birrea, Kirkia acuminata and Rhus lancea seeds. Anim. Feed Sci. Technol. 91, 107-113.

AOAC, 1995. Protein (Crude) in Animal Feed. Method number 990.03. In: Official Methods of Analysis of AOAC International. 16th Edition. Association of Official Analytical Chemists, Arlington, V.A., USA. Volume I, Chapter 4, pages 10-11.

Ayoub, S.M.H., 1985. Flavanol molluscicides from the Sudan Acacias. Int. J. Crude Drug Res. 23, 87-90.

Baba, A.S.H., Castro, F.B. \& Ørskov, E.R., 2002. Partitioning of energy and degradability of browse plants in vitro and the implications of blocking the effects of tannin by the addition of polyethylene glycol. Anim. Feed Sci. Technol. 95, 93-104.

Ben Salem, H., Atti, N., Priolo, A. \& Nefzaoui, A., 2002. Polyethylene glycol in concentrate or feed blocks to deactivate condensed tannins in Acacia cyanophylla Lindl. Foliage. 1. Effects on intake, digestion and growth by Barbarine lambs. Anim. Sci. 75, 127-135.

France, J., Dhanoa, M.S., Theodorou, M.K., Lister, S.J., Davies, D.R. \& Isac, D., 1993. A model to interpret gas accumulation profiles with in vitro degradation of ruminant feeds. J. Theoretical Biol. 163, 99-111.

Frutos, P., Hervas, G., Ramos, G., Giraldez, F.J. \& Mantecon, A.R., 2002. Condensed tannin content of several shrub species from a mountain area in northern Spain, and its relationship to various indicators of nutritive value. Anim. Feed Sci. Technol. 95, 215-226.

Fuller, K.W., 1967. Automated determination of sugars. In: Automation in Analytical Chemistry, Vol II, European Technicon Symposium, Paris, France. pp. 57.

Getachew, G., Makkar, H.P.S. \& Becker, K., 2000a. Effect of polyethylene glycol on in vitro degradability of nitrogen and microbial protein synthesis from tannin-rich browse and herbaceous legumes. Br. J. Nutr. 84, 73-83.

Getachew, G., Makkar, H.P.S. \& Becker, K., 2000b. Tannins in tropical browses: Effects on in vitro microbial fermentation and microbial protein synthesis in media containing different amounts of nitrogen. J. Agric. Food Chem. 48, 3581-3588.

Hagerman, A.E. \& Butler, L.G., 1989. Choosing appropriate methods and standards for assaying tannins. J. Chem. Ecol. 15, 1795-1810.

Jones, D.E., 1965. Banana tannin and its reaction with polyethylene glycols. Nature 205, 299-300.

Jones, R.J. \& Palmer, B., 2000. In vitro digestion studies using ${ }^{14} \mathrm{C}$ - labelled polyethylene glycol (PEG) 4000: comparison of six tanniniferous shrub legumes and the grass Panicum maximum. Anim. Feed Sci. Technol. 85, 215-221.

Jones, R.J., Meyer, J.H.F., Bechaz, M. \& Stoltz, M.A., 2000. An approach to screening potential pasture species for condensed tannin activity. Anim. Feed Sci. Technol. 85, 269-277.

Jones, W.T. \& Mangan, J.L., 1977. Complexes of the condensed tannins of sainfoin (Onobrychis viciifolia Scop.) with fraction 1 leaf protein and with submaxillary mucoprotein, and their reversal by polyethylene glycol and pH. J. Sci. Food Agric. 28, 126-136.

Khazaal, K.A., Boza, J. \& Ørskov, E.R., 1994. Assessment of phenolics-related antinutritive effects in Mediterranean browse: a comparison between the use of the in vitro gas production technique with or without insoluble polyvinylpyrrolidone or nylon bag. Anim. Feed Sci. Technol. 49, 133-149.

Kibon, A. \& Maina, A.H.B., 1993. Dry Acacia sieberiana pods as a supplement to a low quality forage diet for growing lambs in Northern Nigeria. Trop. Anim. Health Prod. 25, 59-64.

Komolong, M.K., Barber, D.G. \& McNeill, D.M., 2001. Post ruminal protein supply and N retention of weaner sheep fed on a basal diet of lucerne hay (Medicago sativa) with increasing levels of quebracho tannins. Anim. Feed Sci. Technol. 92, 59-72.

Makkar, H.P.S., Blümmel, M. \& Becker, K., 1995. Formation of complexes between polyvinyl pyrrolidones or polyethylene glycols and tannins, and their implication in gas production and true digestibility in in 
vitro techniques. Br. J. Nutr. 72, 897-913.

Makkar, H.P.S., Blummel, M. \& Becker, K., 1999. Potential and limitations of in vitro gas methods for studying the effects of plant defensive compounds on rumen fermentation. In: Recent Advances of Research in Antinutritional Factors in Legume Seeds and Rapeseed. Eds Jansman, A.J.M., Huisman, J. \& Van der Poel, A.F.B., Wageningen Press, Wageningen. pp. 173-178.

Mauricio, R.M., Mould, F.L., Dhanoa, M.S., Owen, E., Channa, K.S. \& Theodorou, M.K., 1999. A semiautomated in vitro gas production technique for ruminant feedstuff evaluation. Anim. Feed Sci. Technol. 79, 321-330.

McSweeney, C.S., Palmer, B., Bunch, R. \& Krause, D.O., 1999. In vitro quality assessment of tannincontaining tropical shrub legumes: protein and fibre digestion. Anim. Feed Sci. Technol. 82, 227-241.

Mlambo, V., Mould, F.L., Sikosana, J.L.N., Smith, T., Owen, E. \& Mueller-Harvey, I., 2008. Chemical composition and in vitro fermentation of tannin-rich tree fruits. Anim. Feed Sci. Technol. 140, 402-417.

Mlambo, V., Smith, T., Owen, E., Mould, F.L., Sikosana, J.L.N. \& Mueller-Harvey, I., 2004. Tanniniferous Dichrostachys cinerea fruits do not require detoxification for goat nutrition: in sacco and in vivo evaluations. Livest. Prod. Sci. 90, 135-144.

Mueller-Harvey, I., 2006. Unravelling the conundrum of tannins in animal nutrition and health. J. Sci Food Agric 86, 2010-2037.

Ncube, S. \& Mpofu, D., 1994. The nutritive value of wild fruits and their use as supplements to veld hay. Zimb. J. Agric. Res. 32, 71-77.

Nelson, K.E., Pell, A.N., Doane, P.H., Giner-Chavez, B.I. \& Schofield, P., 1997. Chemical and biological assays to evaluate bacterial inhibition by tannins. J. Chem. Ecol. 23, 1175-1195.

Porter, L.J., Hrstich, L.N. \& Chan, B.G., 1986. The conversion of procyanidins and prodelphinidins to cyanidin and delphinidin. Phytochemistry 1, 223-230.

Reed, J.D., Horvarth, P.J., Allen, M.S. \& Van Soest, P.J., 1985. Gravimetric determination of soluble phenolics including tannins from leaves by precipitation with trivalent ytterbium. J. Sci. Food Agric. $36,255-261$.

Salawu, M.B., Acamovic, T., Stewart, C.S. \& Hovell, F.D.D., 1997. Quebracho tannins with or without Browse Plus (a commercial preparation of polyethylene glycol) in sheep diets: effect on digestibility of nutrients in vivo and degradation of grass hay in sacco and in vitro. Anim. Feed Sci. Technol. 69, 67-78.

SAS, 1996. User's guide: Statistics, Version 6.12. SAS Institute, Inc. Cary, N.C., USA.

Self, R., Eagles, J., Galletti, G.C., Mueller-Harvey, I., Hartley, R.D., Lea, A.G.H., Magnolato, D., Richli, U., Gujer, R. \& Haslam, E., 1986. Fast atom bombardment mass spectrometry of polyphenols (syn. vegetable tannins). Biomed. Environm. Mass Spectrom., 13, 449-468.

Silanikove, N., Nitsan, Z. \& Prevolotsky, A., 1994. Effect of daily supplementation of polyethylene glycol on intake and digestion of tannin-containing leaves (Ceratonia siliqua) by sheep. J. Agric. Food Chem. 42, 2844-2847.

Singleton, V.L. \& Rossi, J.A., 1965. Colorimetry of total phenolics with phosphomolybdic phosphotungstic acid reagents. Am. J. Enol. Vitic. 16, 144-158.

Tanner, J.C., Reed, J.D. \& Owen, E., 1990. The nutritive value of fruits (pods with seeds) from four Acacia spp. compared with extracted Noug (Guizotia abyssinica) meal as supplements to maize stover for Ethiopian highland sheep. Anim. Prod. 51, 127-133.

Tempel, A.S., 1982. Tannin measuring techniques: A review. J. Chem. Ecol. 8, 1289-1297.

Terrill, T.H., Rowan, A.M., Douglas, G.B. \& Barry, T.N., 1992. Determination of extractable and bound condensed tannin concentration in forage plants, protein concentrate meals and cereal grains. J. Sci. Food Agric. 58, 321-329.

Timberlake, J., Fagg, C. \& Barnes, R., 1999. Field guide to the Acacias of Zimbabwe. CBC Publishing, Harare, Zimbabwe. 160 pp.

Van Soest, P.J., Robertson, J.B. \& Lewis, B.A., 1991. Methods of dietary fibre, neutral detergent fibre and non-starch polysaccharides in relation to animal nutrition. J. Dairy Sci. 74, 3583-3597.

Villalba, J.J. \& Provenza, F.D., 2001. Preference for polyethylene glycol by sheep fed a quebracho tannin diet. J. Anim. Sci. 79, 2066-2074. 
Vitti, D.M.S.S., Abdalla, A.L., Bueno, I.C.S., Silva Filho, J.C., Costa, C., Bueno, M.S., Nozella, E.F., Longo, C., Vieira, E.Q., Cabral Filho, S.L.S., Godoy, P.B. \& Mueller-Harvey, I., 2005. Do all tannins have similar nutritional effects? A comparison of three Brazilian fodder legumes. Anim. Feed Sci. Technol. 119, 345-361.

Waghorn, G.C., Shelton, I.D. \& McNabb, W.C., 1994a. Effects of condensed tannins in Lotus pedunculatus on its nutritive value for sheep. 1. Non nitrogenous aspects. J. Agric. Sci., Camb. 123, 99-107.

Waghorn, G.C., Shelton, I.D., Mcnabb, W.C. \& McCutcheon, S.H., 1994b. Effects of condensed tannins in Lotus pedunculatus on its nutritive value for sheep. 2. Nitrogenous aspects. J. Agric. Sci., Camb. 123, 109-112.

Waterman, P.G. \& Mole, S., 1994. Analysis of Phenolic Plant Metabolites. Blackwell Scientific Publications, London. 248 pp. 